\title{
Response of Rice Varieties to Age of Seedlings and Transplanting Dates
}

\author{
Mishri L Shah ${ }^{1 *}$ and Rambaran Yadav ${ }^{1}$ \\ ${ }^{1}$ Regional Agriculture Research Station, Nepal Agricultural Research Council, Parwanipur, Bara
}

\begin{abstract}
A field experiment was conducted at Regional Agricultural Research Station, Parwanipur in 1998/99 and 1999/00 with an aim to find out the alternate management practices to compensate the loss in the grain yield due to flood. Irrespective of the varieties and transplanting dates, age of seedlings had no effect on grain yield of rice. But transplanting dates had significant effect on grain and grain contributing characters. The yield of rice transplanted at 1 Sept was 25.6 and $37.5 \%$ less in 1998/99 and 1999/00 respectively as compared to rice grain yield of 14 July transplanting. Radha 11 registered the highest grain yield of $4086 \mathrm{~kg} \mathrm{ha}^{-1}$ in $1999 / 00$ and $2662 \mathrm{~kg}$ $\mathrm{ha}^{-1}$ in 1998/99, which was at par to the yield obtained by Sabitri at the same year. The interaction effect of the age of seedlings, transplanting dates and varieties were found significant in both the years. 25 days old seedlings transplanted on 14 July in 1999/00 of rice varieties Masuli and Radha 11, produced statistically the similar yield. Radha 11 was the best among the tested varieties. 25 days old seedlings of Masuli, Basmati, Sabitri and Radha 11 can be recommended to transplant as late as Sept 1.
\end{abstract}

Key words: Age of seedlings, rice, transplanting dates

\section{Introduction}

Rice acreage in the country is 1.55 million ha with an average production of $2.59 \mathrm{t} \mathrm{ha}^{-1}$, which is much less as compared to potential yield of the newly developed varieties (MoAC, 1999/00). The major factor of low productivity is due to rainfed condition. Nearly $79 \%$ of the rice growing area are under rainfed condition which faces prolonged drought or submergence due to excessive rain because of erratic rainfall pattern in the certain years (NARC, 1996). About 7 to $10 \%$ area of total rice growing acreage was found under submerged conditions for 2 to 10 days or even more days. Prevailing of such situations did considerable damage to the rice crop stand. And re-raising of rice seedlings and retransplanting under delayed conditions might not favor for optimum production. The information to tackle the problem caused by flood is not available. Therefore, alternate management strategy needs to be explored. Hence a study was under taken to study the effect of the age of seedling of rice varieties in relation to transplanting dates under rainfed ecosystem.

\section{Materials and Methods}

A field experiment was laid out in $2 \times 5 \times 3$ factorial randomized block design with 3 replications at Regional Agricultural Research Station, Parwanipur $\left(27^{\circ} 04^{\prime} \mathrm{N}\right.$ and $\left.84^{\circ} 58^{\prime} \mathrm{E}\right)$, $115 \mathrm{~m}$ above sea level. Seedlings of 25 and 50 days old of five rice varieties (Basamati, Sabitri, Chaite 4, Masuli and Radha 11) were transplanted on 14 July, 7 Aug, 1 and 26 Sept $1998 / 99$ and 1999/00 wet season. The plot size was kept $4-\times 3-\mathrm{m}$ and with spacings of $20 \mathrm{~cm}$ hill to hill and row to row. Two seedlings hill ${ }^{-1}$ were maintained in both the years. Fertilizer dose of 50:40:30 kg N: $\mathrm{P}_{2} \mathrm{O}_{5}: \mathrm{K}_{2} \mathrm{O}$ ha $^{-1}$ were applied as basal and remaining nitrogen was top dressed 25 days after transplanting. The cultural practices were done as per need of the crop. Data were recorded on heading, maturity days, plant stand $\mathrm{m}^{-2}$, filled grains panicle ${ }^{-1}, 1000$-grain weight and grain yield. The last date of transplanting could not produce the grain, therefore, this treatment had been deleted from the analysis of the variance. The statistical analysis was done using MSTATC program. 


\section{Results and Discussions}

\section{Effect of the age of seedlings}

The age of seedling had significant effect on heading and maturity days. The 50 days old seedling headed and matured earlier as compared to 25 days old seedlings (Table 1). The number of filled grains panicle ${ }^{-1}, 1000$-grain weight, plant stand $\mathrm{m}^{-2}$ and even grain yield were found insignificant. Such results are in agreement with the findings of Shrestha (1975), Mallik and Singh (1976). The differences in heading and maturity days due to seedlings age could not significantly influence the grain yield in both the years.

Table 1. Average yield and yield contributing characters of 5 rice cultivars as influenced by the age of seedlings at transplanting during 1998/99 and 1999/2000

\begin{tabular}{|c|c|c|c|c|c|c|c|c|c|c|c|c|}
\hline \multirow[t]{2}{*}{ Seedling age } & \multicolumn{2}{|c|}{ Heading days } & \multicolumn{2}{|c|}{ Maturity days } & \multicolumn{2}{|c|}{ Plant stand $\mathrm{m}^{-2}$} & \multicolumn{2}{|c|}{ Filled grains panicle $^{-1}$} & \multicolumn{2}{|c|}{ 1000-grain wt, g } & \multicolumn{2}{|c|}{ Grain yield, $\mathrm{kg} \mathrm{ha}^{-1}$} \\
\hline & $98 / 99$ & $\begin{array}{c}99 / 0 \\
0\end{array}$ & $98 / 99$ & $99 / 00$ & $98 / 99$ & $99 / 00$ & $98 / 99$ & $99 / 00$ & $98 / 99$ & $99 / 00$ & $98 / 99$ & $99 / 00$ \\
\hline 25 day old & 124 & 119 & 154 & 147 & 169 & 236 & 94 & 101 & 19.4 & 21.8 & 2203 & 3643 \\
\hline 50 day old & 102 & 104 & 133 & 132 & 174 & 232 & 97 & 98 & 19.2 & 21.1 & 2356 & 3320 \\
\hline F test & $* *$ & $* *$ & $* *$ & $* *$ & ns & $\mathrm{ns}$ & ns & ns & $\mathrm{ns}$ & $\mathrm{ns}$ & $\mathrm{ns}$ & $\mathrm{ns}$ \\
\hline LSD (0.05) & 1.7 & 1.2 & 1.9 & 1.8 & - & - & - & - & - & - & - & - \\
\hline
\end{tabular}

** Significant at $0.1 ; \mathrm{ns}$, Non significant.

\section{Effect of transplanting dates}

The yield contributing characters and grain yield exhibited the poor performances due to heavy attack of brown plant hopper, despite of all measure taken to control in 1998/99 whereas crop was free from brown plant hopper in 1999/00. Transplanting dates had significant or highly significant effects on all characters except 1000-grain weight in both the years. The number of days from seeding to heading and maturity was recorded in the decline trend, as transplantation was delayed. The number of filled grains panicle $\mathrm{e}^{-1}$ and plant stand $\mathrm{m}^{-2}$ followed the same pattern. Grain yield of rice transplanted on 14 July and 7 Aug did not differ significantly in $1998 / 99$. The grain yield of 1 Sept transplanting was 21.7 and $37.8 \%$ less in 1998/99 and 1999/00 respectively as compared to 14 July transplanting. The results are in agreement with the findings of Koirala (1983), Kunwar and Shrestha (1979), Bhurer et al. (1990) who reported that early planting of rice gave higher yields and gradual decline in the grain yields in delayed transplanting. The reason for declining the grain yield might be due to delayed panicle formation and grain filling in the season where temperature and solar radiation was less (IRRI, 1993). It is natural process that the crop which had taken more number of days from seeding to maturity might have a more vigorous and extensive root system, increased growth rate during vegetative growth, more efficient sink formation and greater sink size, greater carbohydrate translocation from vegetative plant parts to the spikelets and longer leaf area index during grain filling period. So, this might be the possible reason to have high yields in earlier transplanting.

Table 2. Effect of the transplanting dates on agronomic characters and grain yield (average of 5 rice cultivars) during $1998 / 99$ and 1999/2000

\begin{tabular}{|c|c|c|c|c|c|c|c|c|c|c|c|c|}
\hline \multirow{2}{*}{$\begin{array}{c}\text { Transplanting } \\
\text { date }\end{array}$} & \multicolumn{2}{|c|}{ Heading days } & \multicolumn{2}{|c|}{ Maturity days } & \multicolumn{2}{|c|}{ Plant stand $\mathrm{m}^{-2}$} & \multicolumn{2}{|c|}{ Filled grains panicle $^{-1}$} & \multicolumn{2}{|c|}{ 1000-grain wt, g } & \multicolumn{2}{|c|}{ Grain yield, $\mathrm{kg} \mathrm{ha}^{-1}$} \\
\hline & 98/99 & $99 / 00$ & $98 / 99$ & $99 / 00$ & 98/99 & $99 / 00$ & $98 / 99$ & $99 / 00$ & $98 / 99$ & $99 / 00$ & 98/99 & $99 / 00$ \\
\hline & 12 & & & & & & & & & & & 4149 \\
\hline 7 Aug & 112 & 112 & 141 & 139 & 163 & 227 & 91 & 106 & 19.4 & 21.4 & 2349 & 3706 \\
\hline
\end{tabular}




\begin{tabular}{lcccccccccccc}
1 Sept & 107 & 110 & 140 & 139 & 150 & 200 & 85 & 90 & 19.5 & 21.1 & 1914 & 2590 \\
\hline F test & $* *$ & $* *$ & $* *$ & $* *$ & $* *$ & $* *$ & $*$ & $*$ & $\mathrm{~ns}$ & $\mathrm{~ns}$ & $* *$ & $* *$ \\
LSD $(0.05)$ & 2.1 & 1.5 & 2.3 & 1.93 & 11 & 14 & 11.3 & 11.6 & - & - & 225 & 184 \\
\hline
\end{tabular}

** Significant at $0.1 ; \mathrm{ns}$, Non significant.

\section{Effect of varieties}

All characters were found statistically highly significant different among rice varieties (Table 3). Chaite 4 took minimum days to heading and maturity and vice versa in Basmati in both the years. Radha 11 registered the maximum number of grains panicle ${ }^{-1}$ and reverse trend was reflected in Chaite 4 in both the years. Radha 11 produced the highest grain yield of $4086 \mathrm{~kg} \mathrm{ha}^{-1}$ in 1999/00 and $2662 \mathrm{~kg} \mathrm{ha}^{-1}$ in 1998/99 which was at par to the grain yield of Sabitri in the same year. The highest grain yield of Radha 11 might be due to more number of filled grains panicle ${ }^{-1}$ and plant stand $\mathrm{m}^{-2}$.

Table 3. Agronomic characters of 5 rice cultivars during 1998/99 and 1999/2000

\begin{tabular}{|c|c|c|c|c|c|c|c|c|c|c|c|c|}
\hline \multirow[t]{2}{*}{ Cultivar } & \multicolumn{2}{|c|}{ Heading days } & \multicolumn{2}{|c|}{ Maturity days } & \multicolumn{2}{|c|}{ Plant stand $\mathrm{m}^{-2}$} & \multicolumn{2}{|c|}{ Filled grains panicle ${ }^{-1}$} & \multicolumn{2}{|c|}{ 1000-grain wt, $g$} & \multicolumn{2}{|c|}{ Grain yield, $\mathrm{kg} \mathrm{ha}^{-1}$} \\
\hline & $98 / 99$ & $99 / 00$ & 98/99 & 99/00 & $98 / 99$ & $99 / 00$ & $98 / 99$ & $99 / 00$ & $98 / 99$ & $99 / 00$ & $98 / 99$ & $99 / 00$ \\
\hline Basamati & 122 & 120 & 156 & 152 & 142 & 223 & 74 & 97 & 22 & 24.2 & 1930 & 3259 \\
\hline Sabitri & 118 & 118 & 150 & 148 & 194 & 241 & 105 & 103 & 19.1 & 21.1 & 2693 & 3421 \\
\hline Chaite 4 & 90 & 89 & 119 & 116 & 202 & 260 & 65 & 75 & 20.2 & 23.8 & 1874 & 3020 \\
\hline Masuli & 120 & 115 & 148 & 142 & 151 & 219 & 125 & 122 & 17 & 17.6 & 2238 & 3623 \\
\hline Radha 11 & 116 & 114 & 144 & 141 & 170 & 226 & 107 & 101 & 18.4 & 20.7 & 2662 & 4086 \\
\hline F test & *** & $* *$ & $* *$ & $* *$ & $* *$ & $* *$ & ** & $* *$ & $* *$ & $* *$ & $* *$ & $* *$ \\
\hline $\operatorname{LSD}(0.05)$ & 2.7 & 1.9 & 2.9 & 2.5 & 14 & 18.3 & 14.6 & 14.9 & 0.83 & 0.6 & 290 & 238 \\
\hline
\end{tabular}

** Significant at 0.1 .

\section{Interaction effect of grain yield}

Three level interaction of age of seedlings, transplanting dates and varieties of two years is presented in Table 4. Two level interactions of three factors are not included, however, the LSD values can be used to compare any two means within a year.

Twenty five days old seedlings of Basamati rice transplanted either on 14 July or 1 Sept could not bring statistical differences in the grain yield and the same case was observed in 50 days old seedlings in 1999 (Table 4). However, 25 days old seedlings of Masuli and Radha 11 produced the grain yield more or less similar to transplanted on 14 July and 7 Aug and significant decline in the grain yields was observed on 1 Sept transplanting in both the years. 50 days old seedlings of Sabitri in first year and all varieties in second year gave significantly high yield Table 4. The grain yield, $\mathrm{kg} \mathrm{ha}^{-1}$ as affected by the interaction effect of age of seedlings, transplanting dates and rice cultivars

\begin{tabular}{|c|c|c|c|c|c|c|c|c|c|c|}
\hline \multirow[b]{3}{*}{ Transplanting date } & \multicolumn{9}{|c|}{25 days old seedlings } & \\
\hline & \multicolumn{5}{|c|}{$1998 / 99$} & \multicolumn{5}{|c|}{$1999 / 00$} \\
\hline & Basmati & Sabitri & Chaite 4 & Masuli & Radha 11 & Basmati & Sabitri & Chaite 4 & Masuli & Radha 11 \\
\hline 14 July & 1997 & 2427 & 2278 & 2672 & 2758 & 3303 & 3738 & 3387 & 4352 & 4506 \\
\hline 7 Aug & 1650 & 3165 & 1480 & 2509 & 2762 & 4026 & 3894 & 2905 & 4116 & 4187 \\
\hline 1 Sept & 1530 & 2504 & 1807 & 1657 & 1843 & 2663 & 3473 & 2941 & 3444 & 3702 \\
\hline
\end{tabular}

transplanted on 14 July as compared to 1 Sept 1 transplanting. 25 days old seedlings of Sabitri, Masuli and Radha 11 produced significantly higher grain yield as compared to 50 days old seedlings transplanted on 1 Sept.

Radha 11 was considered as the best among the test varieties in respect of producing the grain yield. Though, reduction in the grain yield had been noticed to a greater extent on 1 Sept transplanting as compared to 14 July and 7 August transplanting. However, 25 days old seedlings of Basmati, Sabitri, Masuli and Radha 11 might be recommended to transplant as late as 1 Sept. Transplanting of rice irrespective of age of seedlings and varieties should be adjusted up to first week of Aug. Otherwise, decline trend in grain yield might be registered in delayed transplanting. 


\begin{tabular}{|c|c|c|c|c|c|c|c|c|c|c|}
\hline \multicolumn{11}{|c|}{50 days old seedlings } \\
\hline 14 July & 2423 & 3002 & 2309 & 2586 & 3288 & 3577 & 4945 & 3822 & 4576 & 5278 \\
\hline 7 Aug & 2115 & 3233 & 1738 & 2069 & 2771 & 3562 & 3627 & 3190 & 3609 & 3942 \\
\hline $1 \mathrm{Sept}$ & 1865 & 1825 & 1634 & 1933 & 2549 & 2420 & 846 & 1874 & 1639 & 2898 \\
\hline F test & & & $* *$ & & & & & $* *$ & & \\
\hline $\operatorname{LSD}(0.05)$ & & & 712 & & & & & 580 & & \\
\hline
\end{tabular}

** Significant at $1 \%$.

\section{References}

Bhurer, KP, SK Rijal and DN Chaudhary. 1990. Influence of date of seeding and age of seedlings on grain yield of rice under rainfed conditions. Pp. 117-121. In: The Fourth Summer Crops Workshop and Research Program. National Agriculture Research Center, Ministry of Agriculture, Nepal.

IRRI. 1993. Predicted effect of climate change on rice production in South East Asia. Pp. 37. In: Program Report For 1993. International Rice Research Institute, Los Banos, Manila, Philippines.

Koirala, GP. 1983. Effect of seeding dates on performances of improved rice varieties. Paper presented in 11th Summer Crops Workshop held during 30 Jan to 1 Feb 1985 at NRIP, Parwanipur.

Kunwar, MN and GL Shrestha. 1979. Studies on date of seeding, nitrogen levels and varietal responses on rice under Parwanipur conditions. Paper presented in Sixth Summer Crops Seminar held at Department of Agriculture, Hariharbhavan, Lalitpur, Nepal.

Mallik, RN and KN Singh. 1976. Effect of seedling of different variety at different date of plantings. Paper presented in fourth rice crop improvement workshop held at Department of Agriculture, Hariharbhan, Lalitpur, Nepal.

MoAC. 1999/00. Area, production and yield of cereal crops in Nepal. Pp. 4. In: Statistical Information on Nepalese Agriculture 1999/00. Agri. business Promotion and Statistics Division, Ministry of Agriculture and Co-operatives (MoAC), Singh Durbar, Kathmandu, Nepal.

NARC. 1996. Physical Constraints. In: Status of Rice Research and Production in Nepal. Nepal Agricultural Research Council, Khumaltar, Lalitpur, Nepal.

Shrestha, SL. 1975. Effect of seedling age, normal transplanting and re-transplanting (Kheruha or Khaur) on yield of local variety. Paper presented in third rice improvement workshop held during 1 to 3 March 1976 at Department of Agriculture Hariharbhawan, Lalitpur, Nepal. 